\title{
DEVELOPING DESIGN STORM HYDROGRAPHS FOR SMALL TROPICAL CATCHMENTS WITH LIMITED DATA
}

OGUNLELA, A.0.,1 ADEWALE, P.0.1,2 and *ADAMOWSKI, J. F. ${ }^{2}$

http://dx.doi.org/10.4314/ejesm.v5i4.4

Received 10th June 2012; accepted 20th July 2012

\begin{abstract}
Hydrographs are vital tools in the design and construction of water-control structures in urban and rural systems. The purpose of this study was to explore the development of design storm hydrographs for the small tropical catchment with limited data. In this study, Clark's Unit Hydrograph method was used to develop synthetic hydrographs for the University of Ilorin Agricultural and Biosystems Engineering field plot. This method was selected for evaluation because the field plot has very limited stream flow data. Kunrun stream, which is the discharge outlet for the watershed, has no gauge stations. Clark's method was evaluated in this study for peak discharge and storm hydrograph analysis of the field plot. The total area of the field plot measures 18.4 ha and is characterized according to its land use: pasture range land (34\%), cultivated land (49\%), wood or forest land (9\%) and 'dirt' (8\%). The three necessary inputs needed for the development of the synthetic hydrograph using Clark's method are: time of concentration, a storage coefficient, and a time-area histogram. The time of concentration was estimated using the Natural Resources Conservation Service method (NRCS) with the lag time determined from Snyder's equation. The storage coefficient was estimated at $0.75 \mathrm{hr}$ while the time of concentration was $1.98 \mathrm{hr}$. Convolution procedures were used in determining the storm hydrograph from the unit hydrograph. Runoff volume and peak discharge from the unit hydrograph were estimated to be $2.4 \times 10^{4} \mathrm{~m}^{3}$ and $1.02 \mathrm{~m}^{3} / \mathrm{s}$, respectively. According to the 24hour, 100year storm hydrograph, the runoff volume was $5.23 \times 10^{4} \mathrm{~m}^{3}$ while the peak discharge was $2.15 \mathrm{~m}^{3} / \mathrm{s}$. It was found that Clark's Unit Hydrograph Method was very suitable in the development of design storm hydrograph for small tropical catchment with limited data.
\end{abstract}

Keywords: Clark's unit hydrograph, Storm hydrograph, Peak discharge, ungauged watershed.

\section{Introduction}

A synthetic hydrograph is typically used for ungauged watersheds and for anticipated post development conditions. Such conditions are common in Nigeria, as most watersheds lack gauging stations along its rivers and streams discharge outlets. The basic stream flow and rainfall data for planning and designing water management facilities and other hydraulic structures are not available for undeveloped watersheds. The study area falls under this category. In order to accurately design the intended drainage and irrigation structures for the field plot, the hydrologic parameters of the watershed must be identified.

A runoff hydrograph is an expression of surface water discharge over time. It is a reflection of the watershed characteristics which influence the relationship between rainfall and the resulting hydrograph. Synthetic methods are affected by watershed characteristics such as: area of the watershed, overland slope, channel slope, channel area, soil type and vegetation cover, basin length, stream pattern, watershed shape and channel roughness. Each of the watersheds characteristics plays a significant role in shaping the hydrograph of the watershed (Lopez et al., 2005).

Storm pattern and meteorological conditions within the watershed are important in hydrograph development. Specific climatic conditions affecting the area must be known. Rainfall excess is defined as the volume of rainfall available for on-site surface storage, any volumes greater than this become runoff from the site. Runoff is the rate of flow at which rainfall excess is discharged from an area. The runoff coefficient relates the runoff rate to the precipitation rate, as well as relating rainfall excess to precipitation volume (Dery et al., 2009).

Many synthetic unit-hydrograph methods have been proposed in the hydrologic literature regarding the development of hydrographs for ungauged watersheds. These methods were reported in detail by Dayani and Mohamadi (2002). One of the first hydrologists to call attention to these methods was Snyder (1938); further development was later made by Schwartz (1952). They related features of a unit hydrograph

${ }^{1}$ Department of Agricultural and Biosystems Engineering

University of Ilorin, Ilorin, Kwara State, Nigeria

${ }^{2}$ Department of Bioresource Engineering, McGill University,

21111 Lakeshore Road, Ste.-Anne-De-Bellevue, QC, H9X 3V9, 
to watershed characteristics. According to Singh et al. (2008), other methods used to measure ungauged watershed are: SCS (Soil Conservation Service) Synthetic Hydrograph, Unit Hydrograph, Rational Hydrograph, the Santa Barbara Urban Hydrograph (SBUH) Method, the Discrete UnitTime Hydrograph Method, Gray Method, Clark's Instantaneous Unit Hydrograph (IUH) Method and Nash's Synthetic Hydrograph.

Salami (2009) evaluated three methods of storm hydrograph development for the catchment of the lower Niger River basin, located downstream from Jebba Dam. The Snyder, SCS and Gray methods were explored in his study. Salami et al. (2009) also evaluated synthetic unit hydrograph methods for the development of design storm hydrographs for rivers located in the South-West region of Nigeria. In this study, Unit hydrographs were developed based on the methods put forth by Snyder, the Soil Conservation Service (SCS) method, and Gray's method. Neither study considered Clark's method.

Clark developed a synthetic hydrograph based on the Instantaneous Unit Hydrograph (IUH) as reported by Noorbakhsh et al. (2005). This method incorporates many of the factors that influence runoff within a certain area. The method does not require knowledge of spatial runoff distribution. Both the shape of the drainage area and the production of peak flows from concentrated runoff are considered in this method. The results, however, are subject to the accuracy of the developed time-area relationship. The Clark Unit Hydrograph is commonly used for hydrologic design and analysis. It was chosen specifically for this study to explore the development of design-storm hydrographs in areas with limited data (such as the University of Ilorin Agricultural and Biosystems Engineering field plot).

\section{Materials and Methods Study Area}

The study was carried out at the Department of Agricultural and Biosystems Engineering, University of Ilorin, Kwara State, Nigeria (Longitude $\quad 4^{\circ} 35^{\prime} \mathrm{E}, \quad$ Latitude $\quad 8^{\circ} 30^{\prime} \mathrm{N}$ ) characterized by dry and wet seasons. Figure 1 shows the map of the study area. The wet season usually commences in March and ends in October while the dry season spans between November and February. The greatest amount of rainfall occurs between June and September, with mean annual rainfall measuring between $1000 \mathrm{~mm}$ and 1500 mm (Oyegun, 1983; Akintola, 1986). Table 1 shows the mean annual rainfall of Ilorin from 2009 to 2011. Relative humidity varies between $70 \%$ in the dry months, and about $80 \%$ in the wet months approximately (Akoshile et al., 2004). The mean monthly temperature varies between $25^{\circ} \mathrm{C}-29^{\circ} \mathrm{C}$ (Ajadi et al., 2011).

The study field site is on land that slopes eastward at a 5\% gradient. The land measures 510 $\mathrm{m}$ in length and $360 \mathrm{~m}$ in width, creating a total area of approximately 18 ha. The plot is demarcated at the far end by the Kunrun stream, which takes its source from Ile-Apa village, near the Faculty of Agriculture (University of Ilorin) land. The stream is the major outlet of the catchment.

\section{Land Use and Cover}

The study land is primarily used for the cultivation of crops such as maize, sorghum, yam, cassava, cowpea, and okra. There are four main land usages of the field plot: pasture or range land, cultivated land without conservation treatment, wood or sparsely forest land, and dirt (Figure 2). The types of trees growing on the field plot are: locust bean, shea butter, and cassia. The sparsely forested land consists of thin stands, with trees of relatively moderate sizes, and poor cover. The field plot is often subject to burning every dry season by nomadic farmers for grazing. Burning has adverse effects on the physical properties of the soil. The fire removes the top cover, thus exposing it to the direct effect of excess rainfall. This burning effect has made the soil more vulnerable to erosion, which explains the large sediment deposit observed at the discharge outlet. Burning also affects soil infiltration and field capacity. The sub-watershed areas are shown in Table 2. 
Table 1: Mean Annual Rainfall of Ilorin, Kwara State (mm)

\begin{tabular}{lccc}
\hline \multicolumn{1}{c}{ Month } & 2009 & Year & \\
\hline JAN & 6 & 0 & 2011 \\
FEB & 0.5 & 6.5 & 0 \\
MAR & 19.6 & 60.9 & 4.8 \\
APR & 219.2 & 58.2 & 13.5 \\
MAY & 112.1 & 115.5 & 169.1 \\
JUN & 170.6 & 45.1 & 232.4 \\
JUL & 149.5 & 139.1 & 220.2 \\
AUG & 226 & 123.7 & 294.5 \\
SEPT & 231 & 228.8 & 334.6 \\
OCT & 112 & 266.8 & 163.2 \\
NOV & 47.4 & 2 & 0 \\
DEC & 0 & 0 & 0 \\
Maximum & 231 & 266.8 & 294.5 \\
Minimum & 0.5 & 2 & 4.8 \\
Total & 1294 & 1047 & 1451 \\
\hline
\end{tabular}

Source: Lower Niger River Basin Development Authority; Ilorin, Kwara State, Nigeria

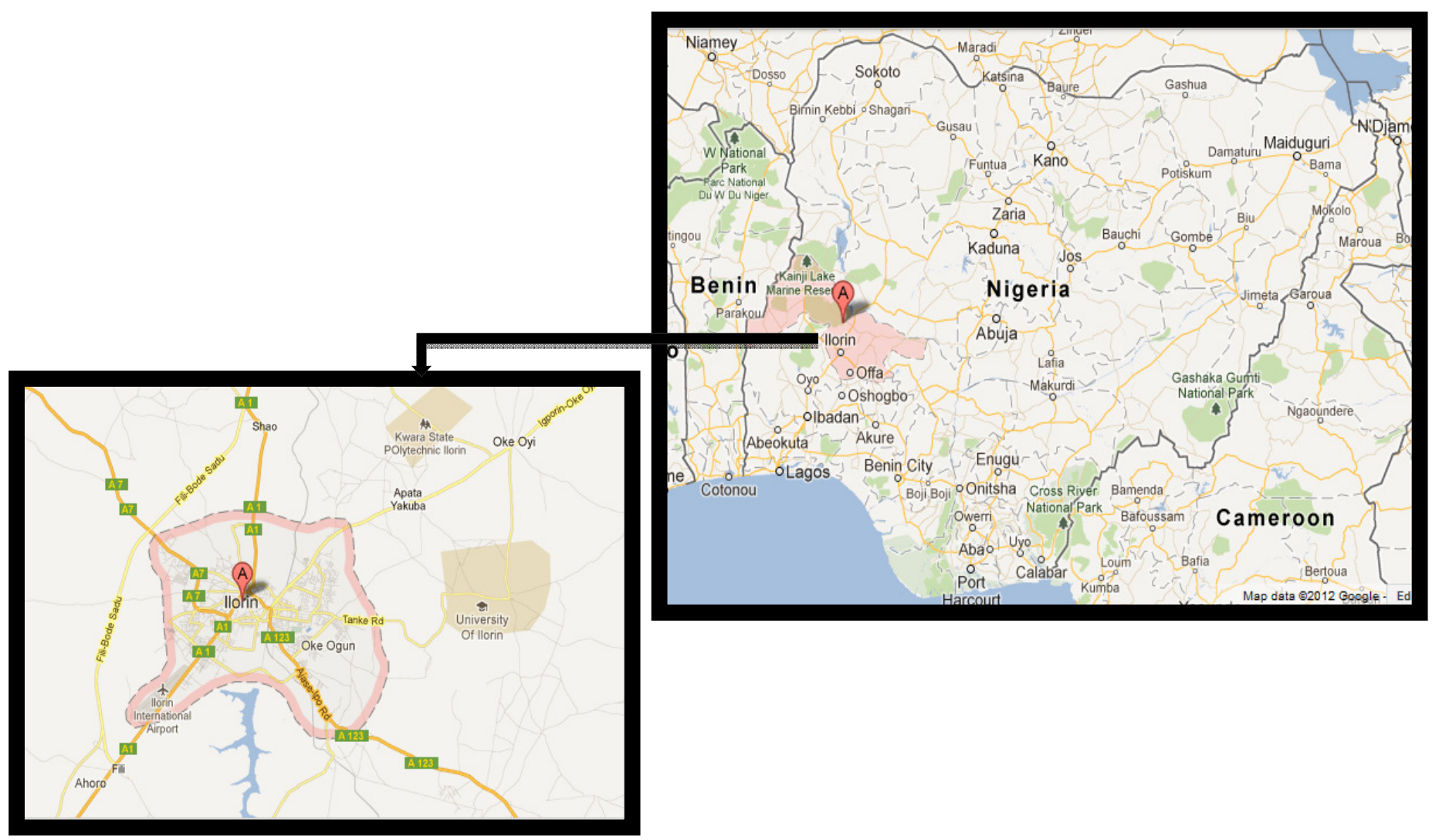

Figure 1 Map of the Study Area

Source: Google Map 
Table 2 The land use and sub-watersheds of the field plot

\begin{tabular}{lccc}
\hline Land use & $\begin{array}{c}\text { Drainage } \\
\text { Area }\left(\mathrm{m}^{2}\right)\end{array}$ & $\begin{array}{c}\text { Drainage } \\
\text { Area }\left(\mathrm{km}^{2}\right)\end{array}$ & $\begin{array}{c}\text { Estimated } \\
\text { Area }(\%)\end{array}$ \\
\hline Pasture range land & 63000 & 0.063 & 34 \\
Cultivated land & 88800 & 0.089 & 49 \\
Wood or forest land & 17176 & 0.017 & 9 \\
Dirt & 14624 & 0.015 & 8 \\
Total & 183600 & 0.184 & 100 \\
\hline
\end{tabular}

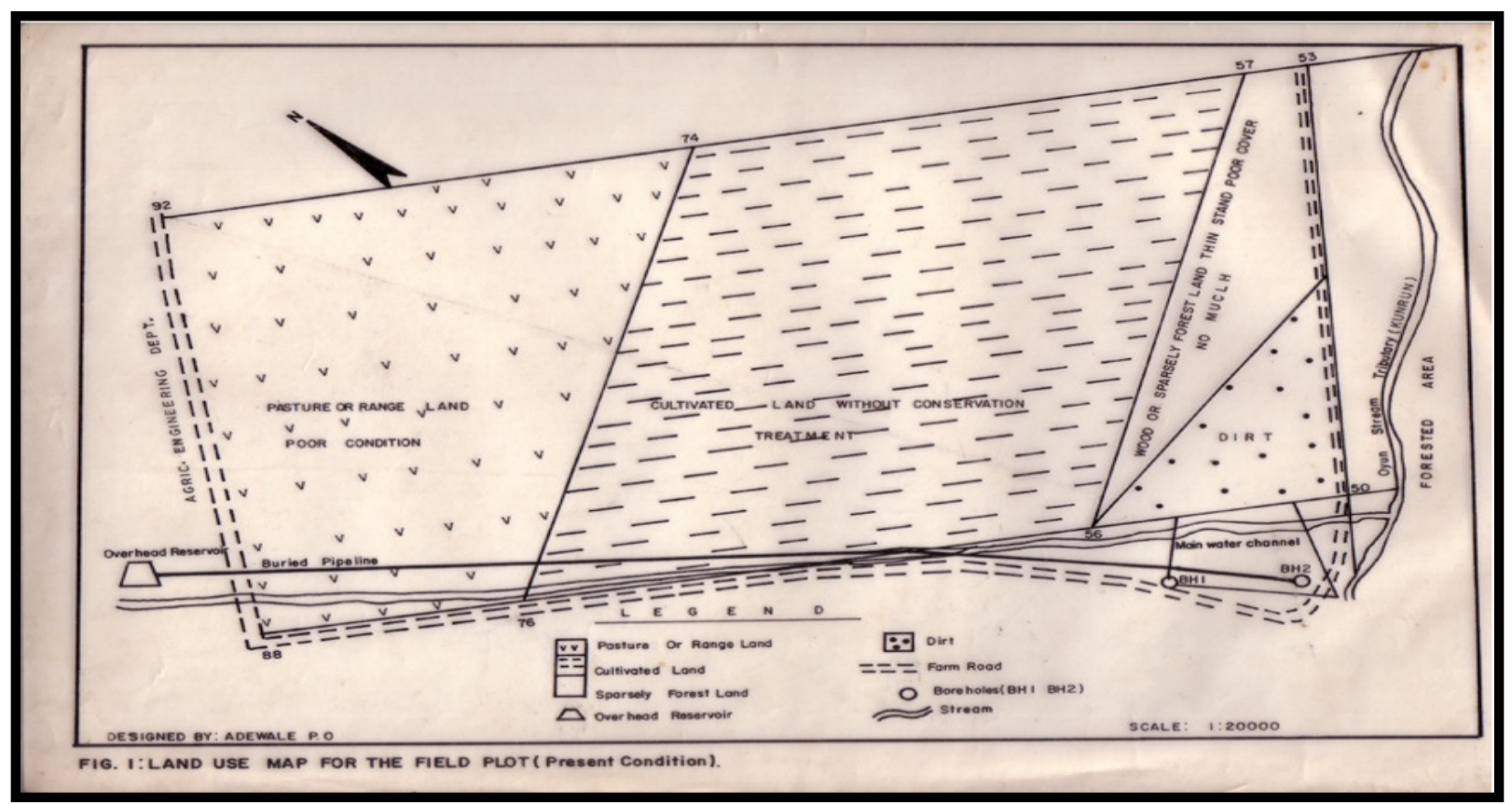

Figure 2 Land Use Map for the Agricultural and Biosystems Engineering Field Plot

\section{Estimation of Watershed Parameters}

The watershed parameters were estimated from the measurable characteristics of the catchment. The field plot resembles a parallelogram in shape (Figure 2), with the centroid located at the intersection of the two diagonal lines. The main runoff channel is 635 $\mathrm{m}$ in length (L); it is located near the overhead reservoir and discharges to the outlet by the Kunrun stream. The distance from the main channel outlet to the centroid of the field plot, $\mathrm{L}_{\mathrm{c}}$, measures $295 \mathrm{~m}$. Snyder's equation employed by the U.S. Army Corps of Engineers (1999) was used to determine the lag time $\left(t_{L}\right)$ and time to peak $\left(\mathrm{t}_{\mathrm{p}}\right)$.
The following equations were applied (Capece, 1988; Wanielista, 1990; Ogunlela, 1997):

$$
\begin{aligned}
t_{L} & =C_{t}\left(L L_{c}\right)^{0.3} \\
C_{t} & =\frac{0.6}{\sqrt{s}} \\
D & =\frac{t_{L}}{5.5} \\
t_{p} & =\frac{D}{2}+L \\
T & =5 t_{p}
\end{aligned}
$$




$$
t_{c}=1.67 t_{L}
$$

where:

$\mathrm{t}_{\mathrm{L}}=\quad$ Lag Time $(\mathrm{hr})$

$\mathrm{C}_{\mathrm{t}}=\mathrm{A}$ coefficient representing variations of watershed slopes and storage

$\mathrm{L}=\quad$ Length of the main channel (mi) from the outlet to the divide

$\mathrm{L}_{\mathrm{c}}=\quad$ Length along the main channel (mi) from the outlet to a channel point nearest to the field plot centroid

$\mathrm{t}_{\mathrm{c}}=$ Time of concentration.

\section{Hydrograph Development via Clark's Unit} Hydrograph Time-Area Method

The field plot was divided into four subcatchments based on land use (Table 2). These sub-catchments were used to develop a timearea chart (Figure 3) so that Clark's method could be applied. Clark's original study was developed based on the Muskingum routing technique. The Clark unit hydrograph relies on the Muskingum storage coefficient, $\mathrm{k}$ (this is termed $\mathrm{R}$ in most references to the Clark method), to represent the attenuation imposed by storage properties of the field plot. In order to develop a synthetic hydrograph using Clark's method, two variables had to first be identified: the storage coefficient $(\mathrm{k})$ and the time interval $(\Delta \mathrm{t}) . \mathrm{k}$ was estimated to be 45 minutes in duration, while $\Delta \mathrm{t}$ was 15 minutes. The storage, $\mathrm{k}$, was approximated to the field plot lag time, while $\Delta \mathrm{t}$ was approximated to the duration of rainfall excess. The time interval, $\Delta \mathrm{t}$ which ranges from $0.3 \mathrm{k}$ to $\mathrm{k}$ was estimated to be 15 minutes. Watershed storage impacts hydrograph translation, which is incorporated in the timearea histogram.

Clark's equation (Singh et al., 2008) is given as:

$$
\mathrm{Q}_{2}=\mathrm{C}_{0} \overline{\mathrm{I}}+\mathrm{C}_{1} \mathrm{Q}_{1}
$$

where, $\mathrm{Q}_{1}$ is the inflow and $\mathrm{Q}_{2}$ is the outflow.

$$
C_{0}=\frac{2 \Delta t}{2 k+\Delta t}
$$

$$
C_{1}=\frac{2 k-\Delta t}{2 k+\Delta t}
$$

For this study, the routing coefficient $\mathrm{C}_{0}$ and $\mathrm{C}_{1}$ were 0.3 and 0.7 , respectively.

Thus,

$$
\mathrm{Q}_{2}=0.3 \overline{\mathrm{I}}+0.7 \mathrm{Q}_{1}
$$

Equation (10) was used to develop the instantaneous unit hydrograph for the field plot.

\section{0-yr, 24hr Storm Hydrograph Development for the Field Plot}

The design storm hydrograph was developed from the unit hydrograph using a convolution procedure (Wanielista, 1990). The 100-year, 24hour rainfall data for the Ilorin field plot was obtained from Ogunlela et al. (1995).

The rainfall-runoff relationship was estimated using the Curve Number method (Ferreira and Smith, 1988; Foster, 1988; Ogunlela, 2001), with the runoff depth (mm) given as:

The synthetic hydrograph from Clark's IUH was developed via:

$\mathrm{X}-\mathrm{hr} \mathrm{UH}=1 / 2\left(\mathrm{IUH}_{\mathrm{t}}+\mathrm{IUH}_{\mathrm{t}-\mathrm{x}}\right)$

$R=\frac{[C N(P / C r+2)-200]^{2}}{C N[C N(P / C r-8)+800]}$

In the equation above, $\mathrm{P}$ is the cumulative rainfall ( $\mathrm{mm}), \mathrm{Cr}$ is a conversion factor (25.4) and $\mathrm{CN}$ is the weighted Curve Number given as:

$$
C N=\sum_{i=1}^{n} f_{i}(C N)_{i}
$$

$(C N)_{\mathrm{i}}$ is the Curve Number for the $\mathrm{i}^{\text {th }}$ category of land use with estimated proportion of total land area $f_{i}$ while $n$ represents the number of land use categories. The SCS Type II rainfall pattern was used in the study. This method was used to create rainfall data to develop dimensionless distributions that were applied to the selected rainfall depth. The estimated rainfall excess for the field plot is shown in Table 3. 
Table 3: Estimated Rainfall Excess for the Field Plots

\begin{tabular}{llcll}
\hline $\begin{array}{l}\text { Time } \\
(\mathrm{hr})\end{array}$ & $\begin{array}{l}\text { Precipitation } \\
\text { Ratio } \mathrm{P}_{\mathrm{x}} / \mathrm{p}_{24}\end{array}$ & $\begin{array}{c}\text { Precipitation } \\
\mathrm{P}_{\mathrm{x}}(\mathrm{mm})\end{array}$ & $\begin{array}{l}\text { Cumulative } \\
\text { Rainfall } \\
\text { Excess }(\mathrm{mm})\end{array}$ & $\begin{array}{l}\text { Incremental } \\
\text { Rainfall } \\
\text { Excess }(\mathrm{mm})\end{array}$ \\
\hline 0 & 0.000 & 0.000 & 0.000 & 0.000 \\
4 & 0.048 & 6.336 & 0.075 & 0.080 \\
8 & 0.120 & 15.840 & 0.010 & 0.070 \\
12 & 0.663 & 87.516 & 1.145 & 1.130 \\
16 & 0.880 & 116.160 & 1.951 & 0.810 \\
20 & 0.952 & 125.664 & 2.240 & 0.290 \\
24 & 1.000 & 132.000 & 2.440 & 0.200 \\
\hline
\end{tabular}

\section{Results and Discussion}

The watershed characteristics, parameters and results are shown in Table 4. The weighted Curve Number of the watershed, 73, reflects the agricultural nature of the catchment. The storage coefficient and the watershed coefficient are adequate indicators of the storage characteristics of the watershed. The Clark method time-area curve (Figure 3) and the time of concentration were used to develop a translation hydrograph.

The unit hydrograph peak discharge was $1.02 \mathrm{~m}^{3} / \mathrm{s}$ while the 100-year, 24-hour storm hydrograph peak discharge was $2.15 \mathrm{~m}^{3} / \mathrm{s}$. The runoff volume from the unit hydrograph was $2.4 \times 10^{4} \mathrm{~m}^{3}$ while the volume from the storm hydrograph was $5.23 \times 10^{4} \mathrm{~m}^{3}$. These results are important for the design of the surface reservoir in the catchment and for the general planning and management of the watershed. These results can also be applied to similar small tropical watersheds. Several other return periods can be produced in the same way the 100-year, 24-hour storm hydrograph was determined because Clark's method is highly flexible. As well, different return periods of hydraulic structures can be designed from this study.
Additional hydrograph modeling of this particular watershed in Nigeria would be beneficial, as would the application of novel hydrological modeling software. The results obtained from the same field plot by using different methods and applications could be compared to validate the hydrological parameters of the watershed (Figure 4).

\section{Conclusion}

The land use and cover variability are effectively analyzed by the isochrones techniques that are part Clark's method. The 100-yr, 24-hr storm hydrograph was developed for a small tropical catchment in Nigeria to explore the development of design storms in situations with minimal data. The unit hydrograph was developed using Clark's method. Synthetic techniques were used to not only determine basic catchment characteristics, but also to estimate hydrological parameters. The time of concentration obtained for the catchment was $1.98 \mathrm{hr}$. Based on these results, it can be stated that the generation of a unit hydrograph through synthetic methods is both useful and effective in situations with minimal data. It can also be inferred that synthetic unit hydrograph methods are suitable for the estimation of ordinates for the development of storm hydrographs for rivers in small watersheds. 


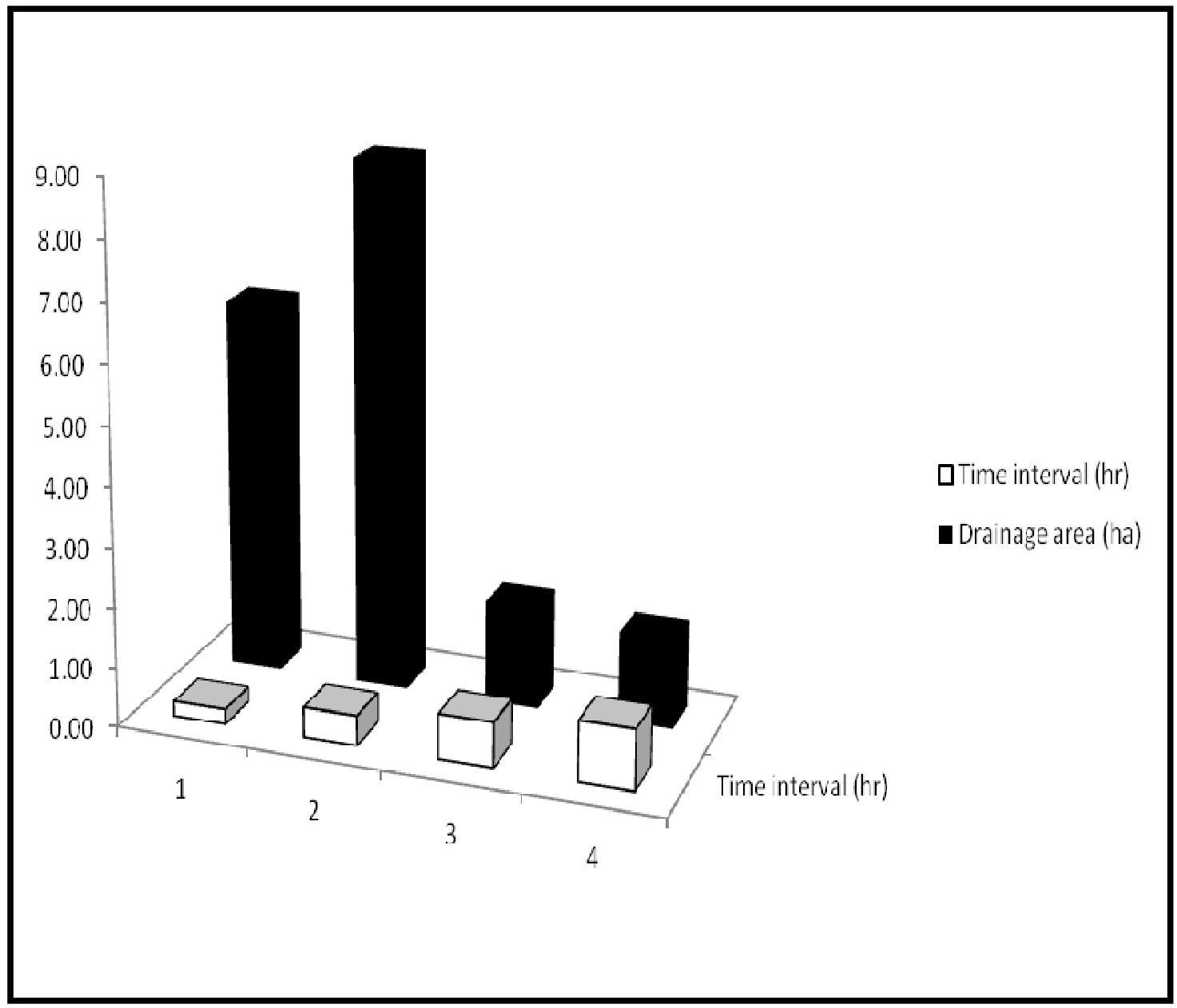

Figure 3 Time-Area Chart for the Field Plot 
Table 4: Catchment Characteristics, Hydrograph Parameters and Results

\section{Estimated Value}

\section{Catchment Characteristics}

Drainage Area, A $\left(\mathrm{m}^{2}\right)$ 184000

Watershed Slope, S (\%) 5

Watershed Coefficient, $\mathrm{C}_{\mathrm{t}}$ 2.6

Length of Main Channel, L (m) 635

Length from the main Channel Outlet to the 295

Catchment Centroid, $\mathrm{L}_{\mathrm{c}}(\mathrm{m})$

\section{Hydrograph Parameters}

Storage Coefficient, k (hr)

Time Interval, $\Delta$ thr)

Lag Time, $\mathrm{t}_{\mathrm{L}}$, (hr)

Rainfall Excess Duration, D (hr)

Base Time, $\mathrm{T}$ (hr)

\section{Study Basin Results}

Weighted Curve Number

Time of Concentration, $t_{c}(h r)$

Unit Hydrograph Peak Discharge, $\mathrm{q}_{\mathrm{p}}\left(\mathrm{m}^{3} / \mathrm{s}\right) \quad 1.02$

100-yr, 24-hr Storm Hydrograph Peak

Discharge, $\mathrm{Q}_{\mathrm{p}}\left(\mathrm{m}^{3} / \mathrm{s}\right)$ 
Ethiopian Journal of Environmental Studies and Management EJESM Vol. 5 No. 42012

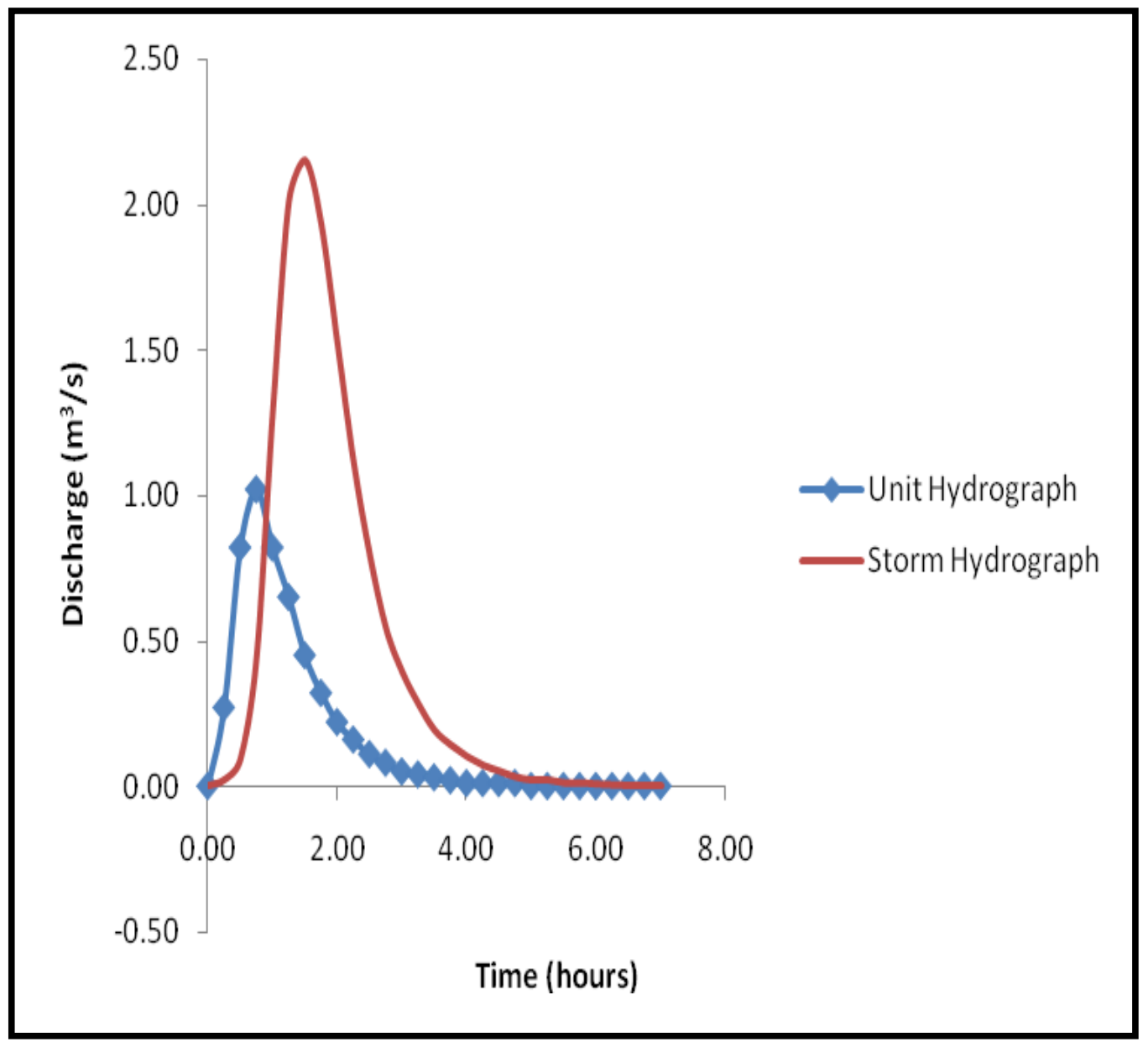

Figure 4 Unit Hydrograph and 100 Year 24 Hour Design Storm Hydrograph 


\section{References}

Ajadi, B.S., Adeniyi, A. and Afolabi, M.T. (2011). Impact of Climate on Urban Agriculture: Case Study of Ilorin City, Nigeria. Global Journal of Human Social Science. 11(1.1), 24-30.

Akintola, J.O. (1986). Rainfall Distribution in Nigeria. 1892-1983. Impact Publisher, Ibadan. Akoshile, C. O., Garnesh, S., Ajibola, T.B., Babatunde, E.B. and Pinker, R.T. (2004). Relative Humidity Variations at Ilorin, Nigeria. Proceedings of the 5th International Conference and 26th Annual General meeting of Nigerian Institution of Agricultural engineers, 26, 234-240.

Clark, C.O. (1945). Storage and the unit hydrograph. Transactions: American Society of Civil Engineers, 110, 1419-1488.

Dayani, S.H. and Mohamadi, K. (2002). Estimation of River Discharge in Ungauged Regions using GIS. $6^{\text {th }}$ Intl. River Eng. Conf. Ahvaz, Iran, 1341-1348.

Dery, S.J., Stahl, K., Moore, R.D., Whitfield, P.H., Menounis, B. and Burford, J.E. (2009). Detection of Runoff Timing Changes in Pluvial, Nival, and Glacial Rivers of Western Canada. Water Resources Research, 45, W04426.

Ferreira, V.A. and Smith, R.E. (1988). The Limited Basis of Physically Based Hydrologic Models. In Proc. Int. Symp. On Modeling in Agricultural, Forest, and Rangeland Hydrology. 10-18. St. Joseph Mich. ASAE.

Foster, G.R. (1988). Development and Use of Models Management of Runoff and Erosion Processes. In Proc. Int. Symp. on Modeling in Agricultural, Forest and Rangeland Hydrology, 156-165. St. Joseph, Mich., ASAE.

Lopez, J.J., Gimena, F.N., Goni, M. and Agirre, U. (2005). Analysis of a Unit Hydrograph Model Based on Watershed Geomorphology Represented as a Cascade of Reservoir. Agricultural Water Management, 77(1-3), 128-143.

Noorbakhsh, M.E., Rahnama, M.B. and Montazeri, S. (2005). Estimation of
Instantaneous Unit Hydrograph with Clark's Method using GIS Techniques. Journal of Applied Science. 5, 455-458.

Ogunlela, A.O. (1997). Hydrologic Response to Land Use Changes on an Ungauged Watershed. In: Tillage Research and Development in Sub-Saharan Africa. Proc. International Soil Tillage Research Organization (ISTRO), Nigeria, 216-225.

Ogunlela, A.O (2001). Predicting Effects of Land Use Changes on Runoff using the Curve Number Method. Nig. Journal of Tropical Engineering, 2, 25-32.

Ogunlela, A.O., Nwa, E.U. and Jatto, B.O. (1995). Runoff Prediction for Major Catchments in Ilorin City, Nigeria. Paper Presented at the $9^{\text {th }}$ Afro-Asian Regional Conference of the International Commission on Irrigation and Drainage (ICID), Algiers, Algeria.

Oyegun, R. (1983). Water Resources in Kwara State, Nigeria. Matanmi and Sons Printing and Publication Co., Ilorin.

Salami, A.W. (2009). Evaluation of Methods of Storm Hydrograph Development. International Egyptian Engineering Mathematical Society IEEMS, Zagazig University Publications, 17-28.

Salami, A.W., Bilewu, S.O. Ayanshola A.M. and Oritola S.F. (2009). Evaluation of synthetic unit hydrograph methods for the development of design storm hydrographs for Rivers in South-West, Nigeria. Journal of American Science, 5, 23-32.

. Am. Geophysical.Union Trans, 19, 447-454.

U.S. Department of Agricultural Soil Conservation Service (USDA, SCS) (1975). National Engineering Handbook, Section 4, Washington, D.C.

U.S Army Corps of Engineers (1999). Groundwater Hydrology. Eng. And Design Manuals, EM 1110-2-1421. Washington, D.C. Wanielista, M.P. (1990). Hydrology and Water Quantity Control. John Wiley and Sons. 